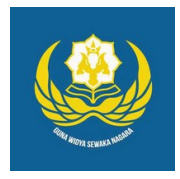

Jurnal Analogi Hukum

Journal Homepage: https://ejournal.warmadewa.ac.id/index.php/analogihukum

\title{
Perjanjian Perkawinan Sebagai Perlindungan Hukum Terhadap Harta Bersama Akibat Perceraian
}

\author{
Ni Kadek Ani*, I Nyoman Putu Budiartha dan Ida Ayu Putu Widiati \\ Universitas Warmadewa, Denpasar-Bali, Indonesia \\ *Arya.kusuma@gmail.com
}

How To Cite:

Ani, N, K., Budiartha, I, N, P., Widiati, I, A, P. (2021). Perjanjian Perkawinan Sebagai Perlindungan Hukum Terhadap Harta Bersama Akibat Perceraian. Jurnal Analogi Hukum. 3 (1). 17-21. Doi: https://doi.org/10.22225/ah.3.1.3021.17-21

\begin{abstract}
In living a household life, it is often that problems arise that cause disputes and end up with divorce between couples. The breakup of marriage will cause problems, one of which is the family's wealth. Marriage agreements are made to anticipate possible problems that occur in a marriage. The problem statement from this study is: (1) how is the arrangement of the Marriage Law in Law Number 1 of 1974 concerning Marriage? (2) How is the legal protection of common property after the verdict of the Constitutional Court Number 69/PUU-XIII/2015 in the event of a divorce? This study is a type of normative law research, since its assessment is carried out through a library study. The Regulation of Marriage Agreements in Law Number 1 of 1974 concerning Marriage, contained in Chapter V, Article 29. The Marriage Agreement was made before the marriage was held and valid since the marriage took place. After the verdict of the Constitutional Court Number 69/PUU-XIII/2015, the Marriage Agreement can be made after the marriage between the husband and wife takes place and must be recorded. This marriage agreement binds the husband, wife, and third party. Marriage agreements provide law protection for both husband and wife to their property if they have to divorce for a reason.
\end{abstract}

Keywords: divorce; marriage; marriage agreement

\begin{abstract}
Abstrak-Dalam menjalani kehidupan rumah tangga, tidak jarang sering timbul permasalahan yang menyebabkan terjadinya perselisihan dan berakhir dengan perceraian di antara pasangan suami istri. Putusnya perkawinan akan menyebabkan permasalahan, salah satunya harta benda (harta kekayaan) keluarga tersebut. Perjanjian kawin dibuat untuk mengantisipasi kemungkinan masalah yang terjadi di dalam suatu perkawinan. Permasalahan yang diangkat dalam penelitian ini adalah, (1) Bagaimana pengaturan Perjanjian Kawin dalam UU Perkawinan No. 1 Tahun 1974? (2) Bagaimana perlindungan hukum atas harta bersama setelah adanya putusan MK No. 69/PUU-XIII/2015 apabila terjadi perceraian? Tipe penelitian ini bersifat normatif, yaitu pengkajiannya dilakukan melalui studi kepustakaan. Pengaturan Perjanjian Kawin pada UU No. 1 Tahun 1974 mengenai Perkawinan, tercantum pada Bab V, Pasal 29. Perjanjian Kawin diadakan sebelum perkawinan dan berlaku sejak tanggal perkawinan. Pasca putusan MK No. 69/PUU-XIII/2015, Perjanjian Kawin memungkinkan diadakan pasca perkawinan antara suami isteri dan wajib dicatatkan. Perjanjian kawin ini mengikat pihak suami, istri, dan pihak ketiga. Perjanjian kawin memberikan perlindungan hukum bagi pihak suami dan pihak istri terhadap hartanya jika mereka harus bercerai karena suatu alasan.
\end{abstract}

Kata kunci: perceraian; perkawinan; perjanjian kawin

\section{Pendahuluan}

Zoonpoliticon merupakan sifat alami manusia, hidup berkelompok yang kemudian dikenal dengan istilah masyarakat merupakan hal yang umum dilakukan manusia. Hidup sendiri tanpa sesama disuatu tempat, bukanlah kodrat manusia sebagai makhluk (Isnaeni, 2016). Secara alamiah, manusia adalah makhluk sosial yang tidak bisa hidup sendiri se- hingga setiap manusia selalu hidup bermasyarakat untuk memenuhi kebutuhan dan kepentingannya (Widowati, 2013). Dengan demikian manusia akan meningkatkan hubungan dirinya terhadap manusia lainnya yang berlawanan jenis.

Perkawinan merupakan caramanusia yang berlawanan jenis untuk mengikatkan dirinya dengan tujuan membangun rumah tangga dan 
melahirkan keturunan untuk keberlangsungan manusia itu sendiri. Perkawinan termasuk sebagai kebutuhan dasar (asasi) setiap manusia, yang tujuannya adalah untuk membentuk keluarga atau rumah tangga yang bahagia dan kekal berdasarkan Ketuhanan Yang Maha Esa (Erwinsyahbana, 2020). Perkawinan itu berlangsung seumur hidup atau perkawinan tersebut diharapkan terjadi hanya sekali dalam kehidupan manusia yang berlangsung seumur hidup atau selama-lamanya serta tidak boleh diputus begitu saja.

Perjanjian kawin di Indonesia, mengatur tentang harta dalam perkawinan dan harta bawaan dari pasangan suami istri. Fakta empiris menunjukkan bahwa perselisihan pasangan suami istri tidak hanya disebabkan oleh perbedaan harta, akan tetapi juga dipicu sebab lainnya (Susanti, 2018). Pembuatan perjanjian kawin oleh UU No. 1 Tahun 1974 secara khusus tertuang dalam Pasal 29 ayat (1), yang didalamnya menyatakan bahwa perjanjian kawin memungkinkan diadakan pada dan atau sebelum tanggal perkawinan oleh pasangan yang melakukan perkawinan, dasar dari diadakannya perjanjian ini adalah kesepakatan kedua belah pihak (suami dan istri) yang memungkinkan untuk dituangkan secara tertulis untuk kemudian didaftarkan pada instansi yang berwenang untuk melakukan pencatatan, yang kemudian memiliki konsekensi hukum terhadap pihak ketiga yang terkait.

Pasca Putusan MK No. 69/PUU-XIII/2015, yang isinya menetapkan perjanjian kawin boleh diadakan setelah perkawinan, dengan catatan bahwa suami isteri tersebut sebelum bercerai hidup rukun, mempunyai keturunan, dan mempunyai akta perkawinan. Sehingga dengan adanya akta perkawinan menjadikan sebuah perkawinan sah secara hukum dan lebih lanjut, untuk sahnya perjanjian perkawinan, wajib dicatatkan pada pegawai pencatat perkawinan.

Untuk membahas lebih lanjut tentang perjanjian kawin ini, Penulis kemudian menetapkan judul: PERJANJIAN PERKAWINAN SEBAGAI PERLINDUNGAN HUKUM TERHADAP HARTA BERSAMA AKIBAT PERCERAIAN. Dan telah menetapkan rumusan masalah sebagai berikut:

Bagaimanakah pengaturan Perjanjian Perkawinan dalam UU No. 1 Tahun 1974 mengenai Perkawinan?

Bagaimanakah perlindungan hukum atas harta perkawian pasca keluarnya putusan MK No. 69/PUU-XIII/2015 apabila terjadi perceraian?
Adapun tujuan dari penelitianini adalah:

Untuk mengetahui pengaturan hukum perjanjian kawin dalam UU No. 1 Tahun 1974 mengenai Perkawinan.

Guna mengetahui perlindungan hukum atas harta perkawinan, pasca keluarnya Putusan MK No. 69/PUU-XIII/2015, apabila terjadi perceraian.

\section{Metode}

Dalam penulisan penelitian ini penulis mempergunakan metode yang bersifat normatif. Penelitian yang dilakukan dengan cara melakukan pengkajian melalui pendekatan konseptual dan pendekatan peraturan perundangundangan. Pendekatan masalah dilakukan dengan melakukan kajian terhadap peraturan peruandang-undangan yang berlaku dan memiliki relevansi dengan permasalahan yang dibahas sekaligus melakukan pendekatan konseptual melalui analisa permasalahan lewat teori hukum yang terdapat pada buku serta literature yang memiliki relevansi dengan penelitian ini. Ini Yaitu:

Sumber Bahan Hukum Dalam Penelitian

Bahan hukum primer (utama),adalah bahan hukum positif yang bersumber pada peraturan perundang-undangan yang masih berlaku di negara Indonesia,seperti norma-norma ataupun kaidah-kaidah dasar seperti:

\section{Th. 1945}

1. UU Dasar Negara Republik Indonesia

\section{Kitab UU Hukum Perdata}

3. UU No. 1 Tahun 1974 mengenai Perkawinan

4. Keputusan Mahkamah Konstitusi 69/ PPU-XIII/2015

b. Bahan hukum sekunder merupakan bahan hukum yang memberikan penjelasanpenjelasan akan teori serta doktrin hukum, yang diantaranya adalah berupa buku-buku bidang hukum, hasil penelitian bidang hukum serta kajian pustaka yang memiliki keterkaitan dengan penelitian ini.

c. Materi atau bahan hukum tersier yaitu materi hukum yang berperan memberi penjelasan ataupun petunjuk mengenai materi hukum primer dan sekunder yang ada, sehingga kedua materi hukum tersebut dapat dipergunakan secara tepat guna, misalnya kamus, ensiklopedia, indeks kumulatif dan sebagainya.

Terkait analisis materi hukum, dilakukan 
pasca terkumpulnya Seluruh materi hukum yang diperlukan, yaitu dulakukan dengan cara mengolah dan menganalisis untuk kemudian diperoleh suatu kebenaran dan berusaha untuk memahami kebenaran tersebut. Bahan hukum yang sudah terkumpul dan telah dikelompokkan kemudian diolah serta dianalisamelalui metode interprestasi hukum yang dilakukan melalui sistematika hukum, diberikan penafsiran dengan argumentasi untuk mendapatkan suatu simpulan yang bersifat tepat, benar, dan ilmiah, serta logis sebagai hasil akhir dari penelitian ini.

\section{Hasil Penelitian dan Pembahasan}

\section{Pengaturan Perjanjian Kawin dalam UU No. 1 Th. 1974 Mengenai Perkawinan}

Dalam UU No. 1 Tahun 1974 mengenai Perkawinan, pasa yang mengatur mengenai Perjanjian Kawin hanya ada dalam pasal 29 yang isinya menyatakan sebagai berikut:

(a). Pada saat atau sebelum perkawinan dilangsungkan, kedua belah pihak calon mempelai, baik pihak istri maupun pihak suami atas persetujuan bersama dapat mengadakan perjanjian tertulis yang disahkan oleh Pegawai Pencatat Perkawinan setelah mana isinya berlaku juga terhadap pihak ketiga sepanjang pihak ketiga memiliki kepentingan;

(b). Bila Perjanjian kawin yang dibuat melanggar batas-batas hukum, agama, dan kesusilaan, maka perjanjian kawin tersebut tidak dapat disahkan;

(c). Perjanjian kawin tersebut berlaku sejak perkawinan dilangsungkan;

(d). Perjanjian kawin yang dibuat dan disahkan tidak dapat diubah selama perkawinan masih berjalan, perubahan hanya dapat dilakukan apabila kedua belah pihak (suami dan istri) setuju untuk merubahnya dan perubahan tersebut tidak boleh merugikan pihak ketiga yang berkepentingan.

Memperhatikan ketentuan Pasal 29, UU Nomor 1 Tahun 1974 tentang Perkawinan, Perjanjian Kawin dapat disahkan oleh Pegawai Pencatat Perkawinan. Pengesahan Perjanjian Kawin sebelumnya dilakukan di Kantor Panitera Pengadilan Negeri yang biasa dicatatkan pada buku pendaftaran yang disediakan khusus untuk itu. Kemudian setelah terbitnya UU Perkawinan Nomor 1 tahun 1974 pendaftaran perjanjian kawin tidak lagi dilakukan pada Kantor Kepaniteraan Pengadilan Negeri, namun langsung dilakukan pada Kantor Catatan Sipil bagi non-muslim dan pada Kantor Urusan Aga- ma bagi yang beragama islam.

Dari putusan Mahkamah Konstitusi sebagaimana dijelaskan diatas, ketentuan Pasal 29 UU No. 1 Tahun 1974 mengenai Perkawinan harus dimaknai bahwa Perjanjian Kawin mulai berlaku sejak perkawinan dilangsungkan oleh para pihak, namun demikian, apabila para-pihak menginginkan lain, hal itu dapat juga disepakati dalam perjanjian yang disepakati.

Dengan terbitnya putusan MK No. 69/PUU -XIII/2015, waktu pembuatan perjanjian kawin tidak lagi dibatasi sebelum atau pada saat perkawianan dilangsungkan, akan tetapi setelah tanggal perkawinanpun para pihak tetap dapat mengadakan perjanjian kawin sepanjang disepakati oleh para pihak, dan perjanjian seperti ini tetap mengikat pihak ketiga lainnya yang memiliki keterkaitan secara hukum. Dan perjanjian kawin yang dibuat pasca perkawinan tidak lagi memerlukan penetapan oleh pihak pengadilan, namun cukup dibuat dihadapan Pejabat Notaris yang akan dituangkan dalam bentuk Akta Otentik.

Pada prinsipnya Perjanjian Kawin secara hukum berlaku epektif sejaktanggal perkawinan dilangsungkan, dan akan tetap mengikat para pihak sepanjang umur perkawinan. Perjanjian Kawin dimungkinkan akan berakshir secara hukum dalam kondisi sebagai berikut:

Perjanjian perkawian yang dibuat dalam bentuk perjanjian accessoir dengan lembaga perkawinan, yaitu timbulnya perjanjian kawin sebagai akibat dari adanya perkawinan, sehingga pada saat perkawinan itu harus berakhir maka secara otomatis perjanjian kawinnya juga akan ikut berakhir.

Adanya Pencabutan secara bersama-sama oleh para pihak yang membuatnya, artinya berakhirnya perjanjian kawin ini dilakukan atas dasar kesepakatan para pihak untuk mengakhirnya yang kemudian disepakati untuk dilakukan pencabutan secara bersama-sama. Selanjtunya bukti pencabutan tersebut dilakukan pendaftaran terhadap instansi yang sebelumnya dilakukan pendaftaran perjanjian kawin. Namun demikian pencabutan perjanjian kawin ini yang boleh dilakukan terhadap hal-hal yang belum terjadi, sedangkan terhadap hal-hal yang telah terjadi dimasa lampau tidak bisa disepakati pencabutannya. Hal ini dimaksudkan karena asas pencabutan ini tidak dapat berlaku surut yang sangat mungkin merugikan pihak ketiga lainnya.

Dilakukan pembatalan perjanjian kawin melalui putusan pengadilan. Hal ini dapat dil- 
akukan terhadap perjanjian kawin yang mengandung cacat secara hukum baik yang berkaitan dengan subjek perjanjian yang tidak memenuhi syarat yang ditetapkan oleh UU maupun karena objek dari perjanjian yang melanggar UU sehingga secara hukum dapat dilakukan pembatalan melalui putusan pengadilan.

\section{Perlindungan Hukum Terhadap Harta Bersa- ma Setelah Adanya Putusan MK No. 69/PUU- XIII/2015 Bila Terjadi Perceraian}

Adapun akibat hukum dari dibuatnya Perjanjian Kawin adalah sebagai berikut:

a. secara hukum Perjanjian kawinakan mengikat para pihak (suami dan istri);

b. selain mengikat para pihak yang membuatnya, perjanjian kawin secara hukum juga memaksa pihak ketiga untuk menghormatinya sepanjang perjanjian kawin tersebut telah memenuhi prosedur hukum yang sah;

c. perubahan terhadap Perjanjian kawin hanya mungkin dilakukan apabila ada kesepakatan antara para pihak yang membuatnya, dan pada prinsipnya perubahan tersebut tidak boleh merugikan pihak ketiga lainnya, serta harus melalui proses pengesahan yang diatur dalam peraturan perundangan yang berlaku.

Selanjutnya terkait sarana atau perangkat perlindungan hukum atas perjanjian kawin dapat dibedakan menjadi dua yaitu:

1. yang bersifat preventif yaitu, yaitu perlindungan hukum yang dilakukan sebelum terbitnya putusan pemerintah yang bersifat definitive (bestermmingplanen)yang atasnya rakyat dapat mengajukan keberatan (inspraak), atau diminati pendapatnya menenai keputusan tersebut (M.Hadjon, 2011). Tujuannya dari sarana perlindungan ini adalah untuk mencegah munculnya sengketa.Sarana Perlindungan hukum ini sangat besar maknanya bagi pemerintahan untuk membuat pemerintah lebih berhati-hati dalam menerbitkan suatu putusan yang pada dasarnya dikordinir oleh diskresi.

2. yang bersifat represif, merupakan perlindungan hukum yang tujuan utamanya adalah menyelesaikan permasalahan atau sengketa yang telah muncul. Dalam hal ini Pengadilan Umum dan Peradilan Administrasi Negara yang berperan dominan untuk melakukan tindakan represif untuk mencegah pelanggaran hukum dan melindungi kepentingan hukum masyarakat secara luas dan bersifat hakiki.

Memperhatikan uraian di atas mengenai perlindungan hukum, dalam memberikan perlindungan hukum terhadap pihak yang bersengketa penting adanya peraturan yang jelas sebagai landasannya, dalam hal ini perlindungan hukum terhadap harta bersama dalam perkawian pasca ditetapkannya Putusan MK No. 69/PUU-XIII/2015bila terjadi perceraian.

Menyimak ketentuan Putusan MKNo. 69/ PUU-XIII/2015 di atas dapat disimpulkan bahwa: Perjanjian Kawin dapat dibuat setelah perkawinan antara suami isteri berlangsung, dengan catatan bahwa suami isteri tersebut sebelum bercerai hidup rukun, mempunyai keturunan, dan mempunyai akta perkawinan. Oleh karena itu Putusan MKNo. 69/PUU-XIII/2015 ini mempasilitasi kesempatan kepada suami istri yang dalam perkawinannya tidak memiliki Perjanjian Kawin, kemudian dengan adanya Putusan MK No. 69/PUU-XIII/2015 bisa membuat Perjanjian Kawin setelah perkawinan terjadi, sepanjang pembuatan perjanjian tersebut tidak menabrak kaidah hukum, agama maupun kaidah kesusilaan serta tidak merugikan pihak ketiga.

Dengan adanya Perjanjian Kawin dalam sebuah perkawinan, maka pasangan yang benarbenar mengalami perceraian tidak akan kerepotan tentang berapa banyak masing-masing memperoleh harta kawin yang dimiliki.Pembagian harta gono gini atau harta bersama diharapkan dilakukan dengan cara yang adil sehingga bisa memberikan rasa keadilan bagi kedua belah pihak yaitu pihak suami dan pihak istri. Apabila pembagian harta bersama terjadi perselisihan maka pembagian harta bersama tersebut bisa dilakukan melalu jalur litigasi atau lewat jalur pengadilan.

Selanjutnya, apabila sengketa mengenai harta bersama sampai ke pengadilan maka Perjajian Kawin bisa dipakai sebagai alat bukti, karena perjanjian perkawinan yang dibuat secara sah bisa sebagai alat bukti. Perjanjian Kawin yang dibuat oleh Notaris dalam bentuk akta otentik tersebut memiliki kekuatan pembuktian yang sempurna sehingga apabila dalam suatu perkawinan terjadi sengketa maka akta otentik tersebut bisa dipakai sebagai alat bukti yang kuat. Artinya secara hukum pengadilan harus menghormati kebenaran formil dan materiil yang tertuang dalam akta otentik yang dihadirkan didepan persidangan sebagai alat bukti, terkecual pihak lawan dapat membuktikan sebaliknya. Hal ini merupakan bagian dari perlindungan hukum yang bersifat refresif.

\section{Simpulan}

Dari pembahasan tersebut diatas dapat 
disimpulkan antara lain:

Pengaturan Perjanjian Kawin dalam UU. No. 1 Tahun 1974 mengenai Perkawinan, terdapat pada Bab V, Pasal 29. Yang menyatakan bahwa Perjanjian Kawin diadakan sebelum atau pada tanggal perkawinan terjadidan berlaku sejak tanggal perkawinan terjadi, serta Perjanjian Kawin tidak boleh menabrak kaidah hukum, kaidah agama, ataupun kesusilaan, dan tidak diperkenankan dilakukan perubahan sepihak dan atau tanpa disepati oleh para pihak yang membuatnya. Selian itu, perubahan tersebut juga tidak boleh merugikan pihak ketiga.

Perlindungan hukum terhadap harta bersama setelah adanya putusan Mahkamah Konstitusi Nomor 69/PUU-XIII/2015 apabila terjadi perceraian, yakni dapat dilakukan dengan pembuatan sebuah perjanjian kawin, yang dapat dibuat setelah perkawinan antara suami isteri berlangsung dan perjanjian kawin tersebut wajib dicatatkan agar mengikat bagi pihak ketiga, selain mengikat terhadap kedua pihak yakni suami dan isteri. Selain itu, Perjanjian Kawin juga memberikan perlindungan hukum bagi pihak suami dan pihak istri terhadap hartanya jika di kemudian hari mereka harus bercerai karena suatu alasan.

\section{DAFTAR PUSTAKA}

Erwinsyahbana, T. (2020). Sistem Hukum Perkawinan Pada Negara Hukum Berdasarkan Pancasila. Jurnal Ilmu Hukum, 3(1). Retrieved from https:// media.neliti.com/media/ publications/9129-ID-sistem-hukumperkawinan-pada-negara-hukumberdasarkan-pancasila.pdf

Isnaeni, M. (2016). Hukum Perkawinan Indonesia. Surabaya: PT. Revka Petra Media.

M.Hadjon, P. (2011). Perlindungan Hukum Bagi Rakyat di Indonesia. Surabaya: Peradaban.

Susanti, D. O. (2018). Perjanjian Kawin Sebagai Bentuk Perlindungan Hukum Bagi Pasangan Suami Istri (Perspektif Maqashid Syari'ah). Jurnal Studi Dan Penelitian Hukum Islam, 1(2). Retrieved from http://jurnal.unissula.ac.id/ index.php/ua/article/ download/2456/2045
Widowati, C. (2013). Hukum Sebagai Norma Sosial Memiliki Sifat Mewajibkan. Adil Jurnal Hukum, 4(1). Retrieved from https://academicjournal.yarsi.ac.id/ index.php/Jurnal-ADIL/article/view/31 